\title{
Article \\ Preparation of MgGa Layered Double Hydroxides and Possible Compositional Variation
}

\author{
Rattanawadee (Ploy) Wijitwongwan ${ }^{1}$, Soontaree (Grace) Intasa-ard ${ }^{2} \mathbb{C}$ and Makoto Ogawa ${ }^{1, *}$ \\ 1 School of Energy Science and Engineering, Vidyasirimedhi Institute of Science and Technology (VISTEC), \\ 555 Moo 1 Payupnai, Wangchan, Rayong 21210, Thailand; Rattanawadee.W_s17@vistec.ac.th \\ 2 School of Molecular Science and Engineering, Vidyasirimedhi Institute of Science and Technology (VISTEC), \\ 555 Moo 1 Payupnai, Wangchan, Rayong 21210, Thailand; soontaree.int@gmail.com \\ * Correspondence: makoto.ogawa@vistec.ac.th
}

check for updates

Citation: Wijitwongwan, R.; Intasa-ard, S.; Ogawa, M. Preparation of MgGa Layered Double Hydroxides and Possible Compositional Variation. Nanomaterials 2021, 11, 1206. https:// doi.org/10.3390/nano11051206

Academic Editors:

Christophe Detavernier, Arthur

P. Baddorf and Antonio Di

Bartolomeo

Received: 26 March 2021

Accepted: 26 April 2021

Published: 1 May 2021

Publisher's Note: MDPI stays neutral with regard to jurisdictional claims in published maps and institutional affiliations.

Copyright: (C) 2021 by the authors. Licensee MDPI, Basel, Switzerland. This article is an open access article distributed under the terms and conditions of the Creative Commons Attribution (CC BY) license (https:/ / creativecommons.org/licenses/by/ $4.0 /)$.

\begin{abstract}
Layered double hydroxides (LDHs), shown as the general formula of $\left[\mathrm{M}^{2+}{ }_{1-\mathrm{x}} \mathrm{M}^{3+}{ }_{\mathrm{x}}(\mathrm{OH})_{2}\right]^{\mathrm{x}+}$ $\left(\mathrm{A}^{\mathrm{n}-}\right)_{\mathrm{x} / \mathrm{n}} \cdot \mathrm{yH}_{2} \mathrm{O}$, are useful for various applications such as anion exchangers/adsorbents, catalysts and catalysts' supports, and drug/gene carriers due to their structural, compositional and morphological characteristics and their variation. The $x$ value $\left(\mathrm{M}^{3+} /\left(\mathrm{M}^{2+}+\mathrm{M}^{3+}\right)\right.$ ratio $)$ in layered double hydroxides (LDHs), corresponding to the layer charge density, is one of the important parameters for controlling the properties of LDHs. The $x$ values in commonly available LDHs are limited $(0.2<x<0.3)$. In order to obtain LDHs with $x<0.2, \mathrm{Mg}^{2+} \mathrm{Ga}^{3+}-\mathrm{LDH}$ with interlayer iodide were examined. The linear correlation between lattice parameter $a$ and $\mathrm{x}$ value in the products with $\mathrm{x}$ of 0.06-0.24 was seen, suggesting the successful substitution of $\mathrm{Mg}^{2+}$ in the brucite-like sheet with $\mathrm{Ga}^{3+}$. Carbonate and dodecyl sulfate types $\mathrm{MgGa}-\mathrm{LDH}$ were prepared by ion exchange with carbonate anion and reconstruction in aqueous solution of sodium dodecyl sulfate. The products with $\mathrm{x}$ of 0.06 were dispersed in water and hexanol better than those with $\mathrm{x}$ of 0.24 for MgGa-LDHs containing carbonate and dodecyl sulfate, respectively, suggesting effects of the lower layer charge density on the dispersion.
\end{abstract}

Keywords: layered double hydroxides; layer charge density

\section{Introduction}

Layered double hydroxides (LDHs) are a class of layered materials consisting of positively charged brucite-like sheets of metal hydroxide, where some of divalent metal cations $\left(\mathrm{M}^{2+}\right)$ are substituted with trivalent metal cations $\left(\mathrm{M}^{3+}\right)$ to give positive charge as $\left[\mathrm{M}^{2+}{ }_{1-\mathrm{x}} \mathrm{M}^{3+}{ }_{\mathrm{x}}(\mathrm{OH})_{2}\right]^{\mathrm{x}+}$, and the charge compensating interlayer exchangeable anions $\left(\mathrm{A}^{\mathrm{n}-}\right)$. The overall composition is expressed as the following general formula of $\left[\mathrm{M}^{2+}{ }_{1-\mathrm{x}} \mathrm{M}^{3+}{ }_{\mathrm{x}}(\mathrm{OH})_{2}\right]^{\mathrm{x}+}\left(\mathrm{A}^{\mathrm{n}-}\right)_{\mathrm{x} / \mathrm{n}} \cdot \mathrm{yH}_{2} \mathrm{O}$. Owing to the versatile compositional variation of LDHs by the selection of metal ions in the hydroxide sheets and the interlayer anions, as well as their quantity ( $\mathrm{x}$ values in $\left[\mathrm{M}^{2+}{ }_{1-\mathrm{x}} \mathrm{M}^{3+}{ }_{\mathrm{x}}(\mathrm{OH})_{2}\right]^{\mathrm{x}+}\left(\mathrm{A}^{\mathrm{n}-}\right)_{\mathrm{x}} / \mathrm{n}$ ), possible applications of LDHs have been reported such as polymer additives [1], drug/gene carriers [2,3], catalysts and catalysts' supports [4,5] and anion exchangers/adsorbents [6-8]. Various synthetic methods have been examined and developed to prepare LDHs with desired composition and morphology $[9,10]$.

One of the important parameters for controlling the properties of LDHs is the $x$ value, which corresponds to the anion exchange capacity as well as the layer charge density. Preparation of LDHs with varied $x$ values has been examined and the values of $0.2<x<0.3$ are commonly approved for pure LDH phases. Apart from the range of $0.20-0.33$, products are normally mixtures of LDHs and impurity phases [11,12]. These mixtures were obtained in the preparation of MgAl-LDHs [13-19], CaAl-LDHs [20], CaFeLDHs [21], CoFe-LDHs [22,23], and NiAl-LDHs [24] with $x<0.20$. It was thought that the limitation of the $x$ value in pure LDHs was caused by a difference in the ionic radii of 
divalent and trivalent metal cations in framework of LDHs and a large distance between the adjacent interlayer anion in the interlayer space [12].

In order to obtain an $\mathrm{LDH}$ with $\mathrm{x}<0.20, \mathrm{M}^{2+}$ and $\mathrm{M}^{3+}$ shall have similar ionic radii to obtain the substitution of $\mathrm{M}^{2+}$ in the brucite-like sheet with $\mathrm{M}^{3+}$ without phase separation [11]. If compared with CaAl-LDHs, CaFe-LDHs, MgAl-LDHs, and NiAl-LDHs, which have been extensively investigated among available LDHs, MgGa-LDH is composed of similar size ions $\left(\left(\mathrm{R}_{\mathrm{M}}{ }^{2+}-\mathrm{R}_{\mathrm{M}}{ }^{3+}\right) / \mathrm{R}_{\mathrm{M}}{ }^{2+}=47 \%\right.$ for $\mathrm{CaAl}, 36 \%$ for $\mathrm{CaFe}, 26 \%$ for $\mathrm{MgAl}, 22 \%$ for $\mathrm{NiAl}$, and 13\% for MgGa) [25], while the preparation of MgGa-LDHs has been scarcely reported [26-28]. Besides the combination of $\mathrm{M}^{2+}$ and $\mathrm{M}^{3+}$ in the framework of LDHs, a large distance between the adjacent interlayer anions for LDHs with smaller $x$ values may cause a collapse of the interlamellar domain, leading to the phase segregation [11]. Sasaki and his coworkers have proposed the template concept of interlayer cation to obtain lepidocrocite-type layered titanates $\left(\mathrm{A}_{\mathrm{y}} \mathrm{Ti}_{2-\mathrm{y} / 3} \mathrm{Li}_{\mathrm{y} / 3} \mathrm{O}_{4}\right)$ with varied layer charge densities. The lepidocrocite-type layered titanates are one group of layered materials consisting of negatively charged titanate sheets and the charge-balancing interlayer cations. It has been reported that the lepidocrocite-type layered titanates with varied y values were obtained using different interlayer cations $(\mathrm{A}=\mathrm{Cs}, \mathrm{Rb}$ and $\mathrm{K})$ and larger cation gave smaller $\mathrm{y}$ values [29].

In this study, iodide $(0.21 \mathrm{~nm})$ was used as the interlayer anion to avoid possible collapse of the layered structures of MgGa-LDHs due to the size of iodide. Once layered structures of the MgGa-LDHs with varied $x$ formed by coprecipitation, carbonate and dodecyl sulfate forms of the MgGa-LDHs were prepared by the anion exchange with carbonate anion and the reconstruction in aqueous solution of sodium dodecyl sulfate after calcination. The effect of $x$ value on the dispersions of the MgGa-LDHs in water for the carbonate form and in hexanol for the dodecyl sulfate form was examined by the observation of the sedimentation of the solids before and after the storage without agitation.

\section{Materials and Methods}

\subsection{Materials}

Magnesium nitrate hexahydrate $\left(\mathrm{Mg}\left(\mathrm{NO}_{3}\right)_{2} 6 \mathrm{H}_{2} \mathrm{O}\right)$ was obtained from Sigma-Aldrich. Gallium nitrate hydrate $\left(\mathrm{Ga}\left(\mathrm{NO}_{3}\right)_{3} \mathrm{xH}_{2} \mathrm{O}, 99.9 \%\right)$ was purchased from Alfa Aesar. Potassium iodide $(\mathrm{KI})$ and sodium carbonate $\left(\mathrm{Na}_{2} \mathrm{CO}_{3}\right)$ were supplied by Merck Millipore. Potassium hydroxide $(\mathrm{KOH})$ was obtained from Carlo Erba Reagents. Brucite $\left(\mathrm{Mg}(\mathrm{OH})_{2}\right)$ was obtained from Nacalai Tesque. Sodium dodecyl sulfate $\left(\mathrm{C}_{12} \mathrm{H}_{25} \mathrm{NaO}_{4} \mathrm{~S},>95.0 \%\right)$, hexanol $\left(\mathrm{C}_{6} \mathrm{H}_{14} \mathrm{O},>98.0 \%\right)$, and benzene $\left(\mathrm{C}_{6} \mathrm{H}_{6},>99.5 \%\right)$ were supplied by Tokyo Chemical Industry Co., Ltd. These chemicals were used without further purification. Deionized water was obtained from a Milli-Q system (18.2 M $\Omega$-cm, Merck Millipore, Darmstadt, Germany).

\subsection{Synthesis of $M g G a-L D H s$ Intercalated with Iodide}

$\mathrm{MgGa}-\mathrm{LDH}$ with varied $\mathrm{x}$ were prepared by coprecipitation from aqueous solutions at controlled $\mathrm{pH}$. The starting solution was prepared by dissolving $3.84 \mathrm{~g}$ of $\mathrm{Mg}\left(\mathrm{NO}_{3}\right)_{2}$ $6 \mathrm{H}_{2} \mathrm{O}$ and $1.28 \mathrm{~g}$ of $\mathrm{Ga}\left(\mathrm{NO}_{3}\right)_{3} \times \mathrm{H}_{2} \mathrm{O}$ in $20 \mathrm{~mL}$ of deionized water for the preparation of the $\mathrm{MgGa}-\mathrm{LDH}$ with $\mathrm{x}=0.25$. The starting solution was added dropwise to $40 \mathrm{~mL}$ of aqueous solution containing KI (the mole of KI is two times of the total nitrate from the metal salts) with vigorous stirring at $40{ }^{\circ} \mathrm{C}$ under nitrogen gas bubbling. The $\mathrm{pH}$ of the mixture was kept at 11-12 through the reaction by addition of $0.9 \mathrm{M}$ aqueous solution of $\mathrm{KOH}$ as schematically shown in Scheme 1 . The MgGa-LDHs were prepared using the same procedure by varying the $\mathrm{x}$ of $0.20,0.13,0.10,0.09$, and 0.08 in the starting solution. After the reaction, the precipitate was separated from the suspension by centrifugation at 10,000 rpm for $10 \mathrm{~min}$ and washed several times with deionized water. Half of the precipitate was dried at $80^{\circ} \mathrm{C}$ for $24 \mathrm{~h}$ in oven and another half was freeze dried at $-108^{\circ} \mathrm{C}$ for $24 \mathrm{~h}$. The products thus obtained by the coprecipitation followed by drying in oven and in freeze-dryer are designated as $\mathrm{MgGa}(\mathrm{I})-\mathrm{x}$ and $\mathrm{MgGa}(\mathrm{I})-\mathrm{x} \_\mathrm{F}$, respectively, where $\mathrm{x}$ is the ratio of $\mathrm{Ga}^{3+} /\left(\mathrm{Mg}^{2+}+\mathrm{Ga}^{3+}\right)$ in the product as determined by ICP analysis. 


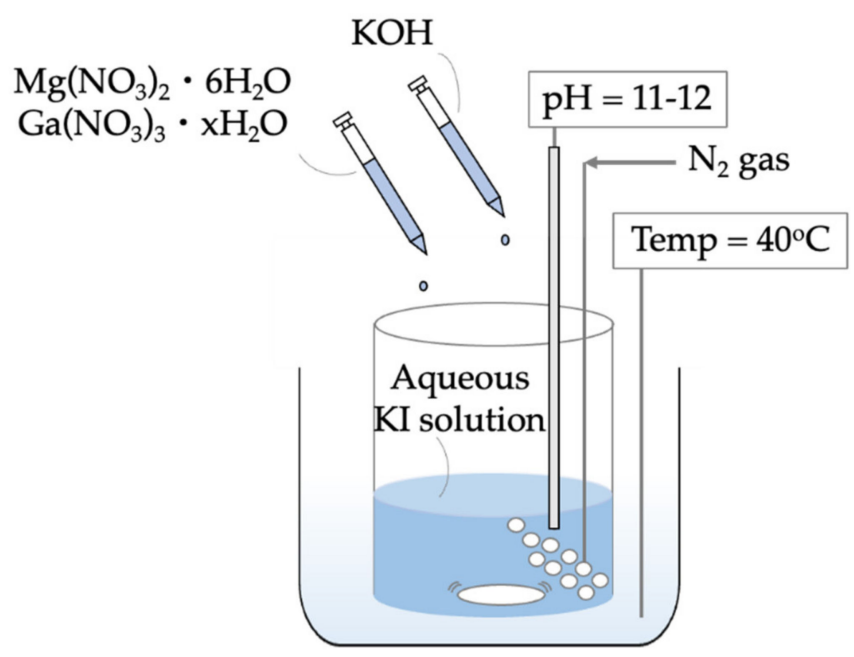

Scheme 1. Experimental setup for the synthesis of MgGa-LDHs intercalated with iodide.

\subsection{Anion Exchange from Iodide to Carbonate in $M g G a-L D H s$}

To the aqueous solution of $\mathrm{Na}_{2} \mathrm{CO}_{3}(1.27 \mathrm{~g}$ in $60 \mathrm{~mL}) 0.3 \mathrm{~g}$ of $\mathrm{MgGa}(\mathrm{I})-\mathrm{x} \_\mathrm{F}(\mathrm{x}=0.24$ and 0.06 ) was added and shaken for $3 \mathrm{~h}$ at room temperature. The solid was separated by the centrifugation at 10,000 rpm for $10 \mathrm{~min}$, washed several times with deionized water, and freeze dried. The products are designated as $\mathrm{MgGa}\left(\mathrm{CO}_{3}\right)-\mathrm{x} \_\mathrm{F}$.

\subsection{Reconstruction of $\mathrm{MgGa}-\mathrm{LDH}$ in Aqueous Solution of Sodium Dodecyl Sulfate}

$\mathrm{MgGa}\left(\mathrm{CO}_{3}\right)-\mathrm{x} \_\mathrm{F}(\mathrm{x}=0.24$ and 0.06$)(0.05 \mathrm{~g})$ were calcined at $500{ }^{\circ} \mathrm{C}$ in air under ambient pressure (the heating rate of $10{ }^{\circ} \mathrm{C} / \mathrm{min}$ ), and then, allowed to react with the aqueous solution of sodium dodecyl sulfate ( 0.50 and $0.15 \mathrm{~g}$ of sodium dodecyl sulfate in $25 \mathrm{~mL}$ of deionized water for the samples with $\mathrm{x}$ of 0.24 and 0.06 , respectively), then shaken for $10 \mathrm{~h}$ at room temperature. After the centrifugation at $10,000 \mathrm{rpm}$ for $10 \mathrm{~min}$, the solid was washed several times with deionized water, and freeze dried. The products are designated as MgGa(DS)-x_F.

\subsection{Preparation of Suspension}

In total, $10 \mathrm{mg}$ of sample was added to $10 \mathrm{~mL}$ of deionized water or hexanol in a vial and sonicated (using Sonorex Digitec, Bandelin) for $2 \mathrm{~min}$.

\subsection{Characterization}

Powder X-ray diffraction (XRD) patterns of the products were recorded at the scan speed of $5.47^{\circ} / \mathrm{min}$ with step size of $0.1002^{\circ}$ using New D8 Advance instrument (Bruker, Billerica, Massachusetts, United States) equipped with $\mathrm{Ni}$ filtered $\mathrm{Cu} \mathrm{K} \alpha$ radiation $(\lambda=0.15406 \mathrm{~nm})$. Infrared spectra were obtained using Frontier Fourier transform infrared spectrophotometer (PerkinElmer, Inc., Waltham, MA, USA) by attenuated total reflection (ATR) mode with the resolution of $4.0 \mathrm{~cm}^{-1}$. In total, 32 scans were recorded for each sample. The composition was determined by ICP analysis (700 Series ICP-OES, Agilent Technologies, Santa Clara, CA, USA) after dissolving a weighed amount of sample with $1 \mathrm{M}$ aqueous solution of $\mathrm{HCl}$. The zeta potential was measured 3 times at $\mathrm{pH}$ of $10-10.5$ without any additives using NanoPlus instrument (Micromeritics, Norcross, GA, USA). Prior to the measurement, $3.5 \mathrm{mg}$ of sample was dispersed in $10 \mathrm{~mL}$ of deionized water under sonication for $30 \mathrm{~min}$. Scanning electron micrographs (SEM) were obtained on a JSM-7610F field emission scanning electron microscope (JEOL, Ltd., Tokyo, Japan) without a coating. 


\section{Results and Discussion}

The XRD patterns of $\mathrm{MgGa}(\mathrm{I})-\mathrm{x}(\mathrm{x}=0.24,0.18,0.11,0.10,0.08$, and 0.06$)$ are shown in Figure $1 \mathrm{~A}$. For $\mathrm{MgGa}(\mathrm{I})-\mathrm{x}(\mathrm{x}=0.24,0.18)$, reflections characteristic to the hydrotalcite structure were seen and the segregation of brucite, which has been seen in the previous reports on the preparation of MgAl-LDHs [13-19], CoFe-LDHs [22,23], and NiAl-LDHs [24] with the $x<0.2$, was not observed. The reflections with the $d$ values of 0.82 and $0.41 \mathrm{~nm}$ were seen, which are consistent with the $\mathrm{d}(003)$ and $\mathrm{d}(006)$ spacings of the reported MgAl-LDHs containing iodide as the interlayer anion, respectively [30].

For the products with smaller $\mathrm{x}$ values $(\mathrm{x}=0.11,0.10,0.08$, and 0.06$)$, the basal reflection of brucite was not observed. A reflection at $2 \theta$ of $20^{\circ}$ and characteristic reflections of brucite at $2 \theta$ of $38,50,62^{\circ}$ (JCPDS No. 07-0239) were seen together with the characteristic reflections of the hydrotalcite with the basal spacing of $0.82 \mathrm{~nm}(0.82 / 0.41 \mathrm{~nm}$ series $)$ in Figure $1 \mathrm{~A}(\mathrm{c}-\mathrm{f})$. The difference in the XRD patterns suggested that the $\mathrm{x}$ value in $\mathrm{MgGa}(\mathrm{I})-\mathrm{x}$, where $\mathrm{x}$ value corresponds to the quantity of interlayer anion, affected the crystal structure of the products. The irregular stacking sequence of LDHs has been proposed on CoFe-LDH with $0.14<x<0.2$ prepared by the post-synthetic oxidation [23]. A reflection revealing the occurrence of the interstratified structure was not observed as proposed by Sasaki [23], it was thought to be caused from the difference in the synthetic methods and the conditions, which affect crystallinity of the products. These observations suggested that $\mathrm{MgGa}(\mathrm{I})-\mathrm{x}$ $(\mathrm{x}=0.11,0.10,0.08$, and 0.06$)$ had an interstratified structure as proposed in Figure 2.
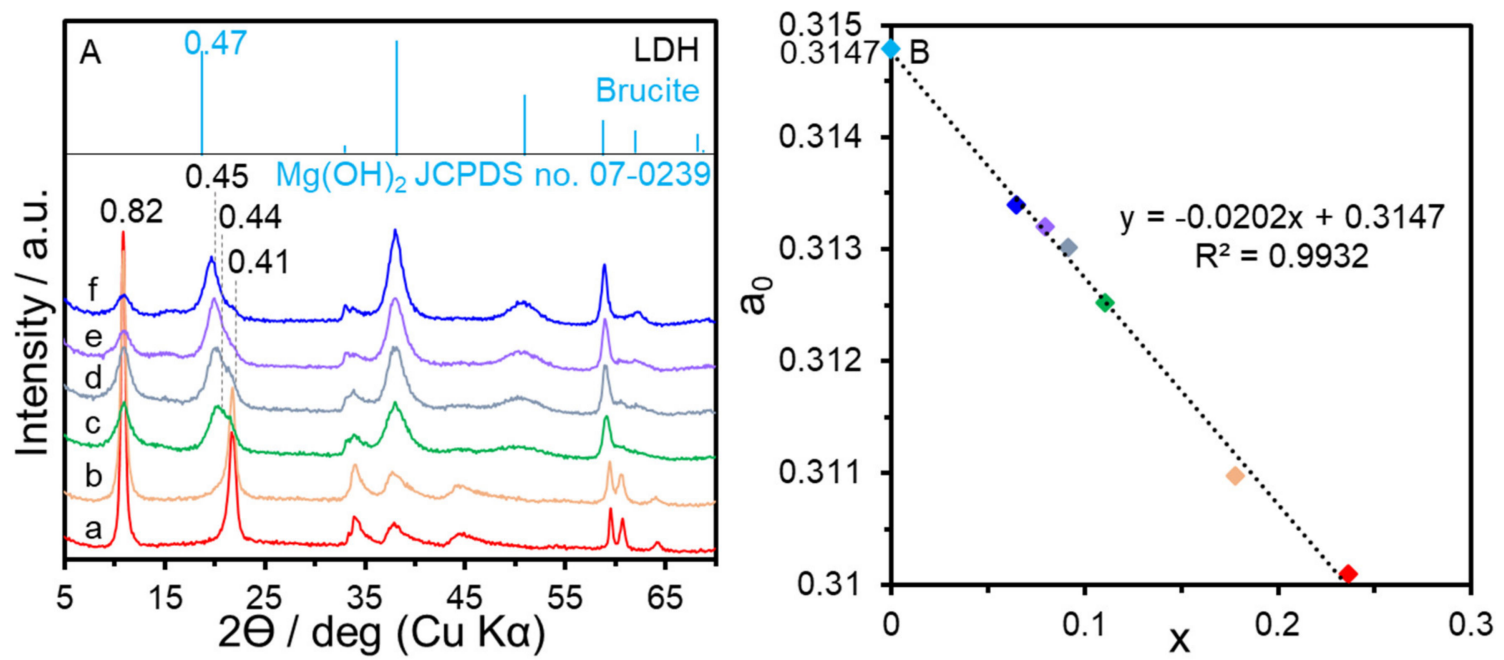

Figure 1. (A) XRD patterns of MgGa(I)-x (x = 0.24 (a), 0.18 (b), 0.11 (c), 0.10 (d), 0.08 (e), and 0.06 (f)). (B) Relation between the lattice parameter $a$ and the $x$ value in the MgGa-LDHs.

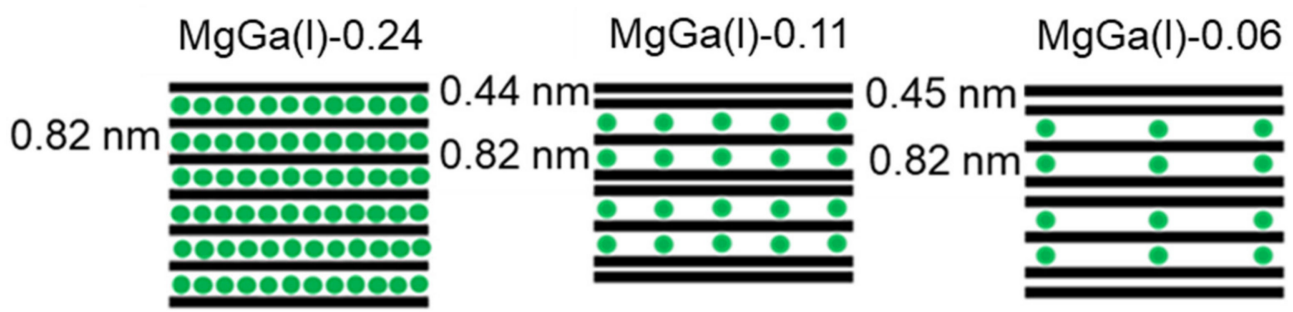

Figure 2. Proposed structure images of $\mathrm{MgGa}(\mathrm{I})-\mathrm{x}(\mathrm{x}=0.24,0.11$, and 0.06$)$.

The lattice parameter $a$, which corresponds to the metal-metal distance in the hexagonal framework of brucite-like sheet [12], can be used to determine the composition from the correlation between the lattice parameter $a$ and $\mathrm{x}$ value. The lattice parameter was smaller when the $x$ values in the products were larger because of the substitution of larger $\mathrm{Mg}^{2+}$ ion $(0.072 \mathrm{~nm})$ by smaller $\mathrm{Ga}^{3+}$ ion $(0.062 \mathrm{~nm})$, where the radii of $\mathrm{Mg}^{2+}$ and $\mathrm{Ga}^{3+}$ with 
coordination number of 6 were reported by Shannon [25]. The correlation between $a$ and $x$ value is shown in Figure 1B, where linear correlation is seen, suggesting the successful substitution of $\mathrm{Mg}$ in the brucite-like sheet with $\mathrm{Ga}$. The correlation was extrapolated to $\mathrm{x}=0$ to obtain $a$ value of $0.3147 \mathrm{~nm}$, which is the same as the lattice parameter $a$ of brucite (0.3147 nm, JCPDS No. 07-0239). In the previous studies on MgAl-LDHs, NiAl-LDHs and $\mathrm{NiFe}-\mathrm{LDH}$ with $\mathrm{x}$ values of $0.1-0.3$, the lattice parameter $a$ extrapolated at $\mathrm{x}=0$ gave smaller values (0.3108 [14] and $0.3125 \mathrm{~nm}$ [18] for MgAl-LDHs and $0.3093 \mathrm{~nm}$ [31] for NiAland $\mathrm{NiFe}-\mathrm{LDHs}$ ) than those of $\mathrm{Mg}(\mathrm{OH})_{2}$ and $\mathrm{Ni}(\mathrm{OH})_{2}$, suggesting that some divalent cations in the brucite-like layer were not substituted with trivalent cations and precipitated separately as metal hydroxides. For the reported carbonate type MgGa-LDHs [32,33] and iodide type CoFe-LDHs [22,23] with $x<0.2$, the products were mixtures of LDHs and brucite. In the present study, the MgGa-LDHs $(x=0.06-0.24)$ containing iodide were obtained without segregation of brucite, which were thought to be possible by the matching of ionic radii of $\mathrm{Mg}^{2+}$ and $\mathrm{Ga}^{3+}$ as well as by the template effect of iodide, which prevented the collapse of LDH.

Figure 3 shows the IR spectra of $\mathrm{MgGa}(\mathrm{I})-\mathrm{x}(\mathrm{x}=0.24,0.11$, and 0.06$)$. The absorption at around $3400-3600 \mathrm{~cm}^{-1}$ was attributed to the $\mathrm{OH}$ stretching vibration of hydroxyl groups hydrogen bonded with water molecules and interlayer anion. The absorption at $3697 \mathrm{~cm}^{-1}$, which was assigned to free hydroxyl groups in the brucite-like sheet [34], was seen for MgGa(I)-0.11 and MgGa(I)-0.06. These IR results supported the proposed stacking sequence of the products $(x=0.24,0.11$, and 0.06$)$ (Figure 2$)$.

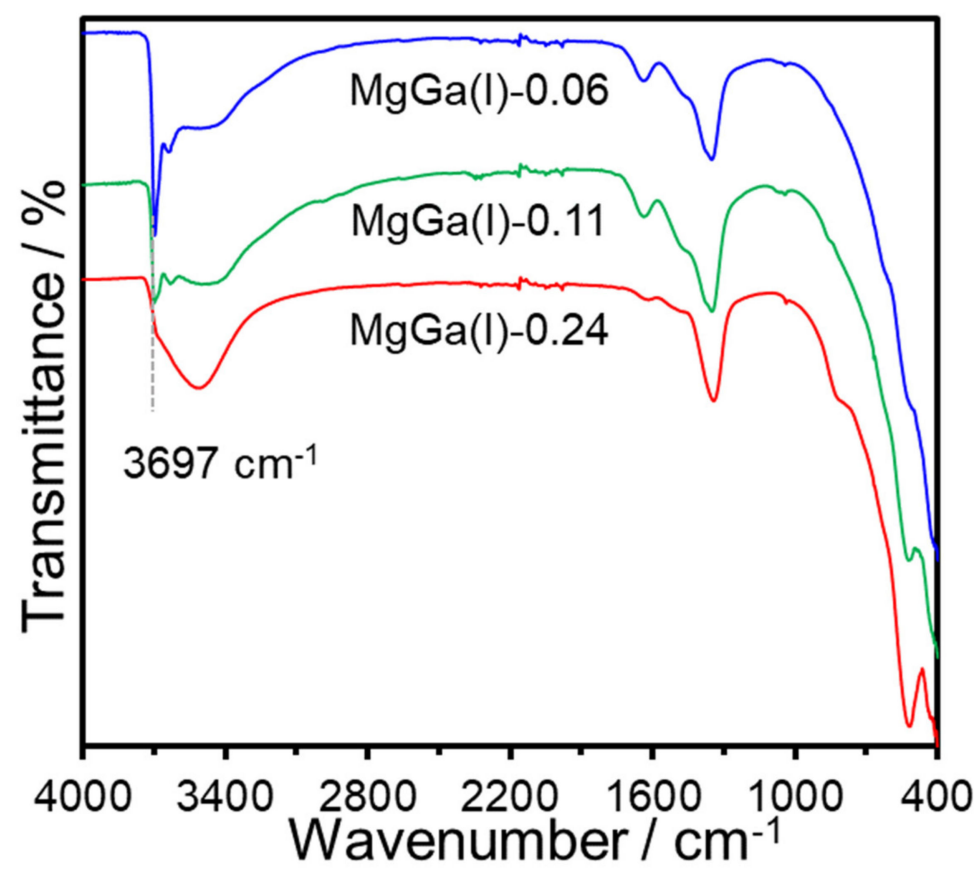

Figure 3. IR spectra of $\mathrm{MgGa}(\mathrm{I})-\mathrm{x}(\mathrm{x}=0.24,0.11$, and 0.06$)$.

The chemical composition of the products, which was determined by ICP analysis, is summarized in Table 1 . The $x$ values $\left(\mathrm{M}^{3+} /\left(\mathrm{M}^{2+}+\mathrm{M}^{3+}\right)\right.$ ratios) of the products prepared at the $\mathrm{pH}$ of the mixture at around 11-12 were smaller than those in the starting solution. It was reported that the loss of $\mathrm{Ga}$ as soluble $\mathrm{Ga}$ complexes in the preparation of $\mathrm{MgGa}-$ $\mathrm{LDH}$ at the $\mathrm{pH}$ above 10 [28]. In addition to the chemical composition determined by ICP analysis, the distribution of $\mathrm{Mg}$ and $\mathrm{Ga}$ in the platy particles was examined by EDS elemental mapping (Figure 4) equipped with SEM, showing the uniform distribution of $\mathrm{Mg}$ and $\mathrm{Ga}$ through the products. The $\mathrm{Ga} / \mathrm{I}$ ratios in the products were larger than 1.0, suggesting the possible coexistence of some anions with $\mathrm{I}^{-}$to compensate the positive charge by the MgGa substitution. As the coexisting interlayer anion, the presence of nitrate 
anion in the products was confirmed by the absorption due to NO stretching vibration at $1342 \mathrm{~cm}^{-1}(\mathrm{MgGa}(\mathrm{I})-0.24)$ and $1350 \mathrm{~cm}^{-1}(\mathrm{MgGa}(\mathrm{I})-0.11$ and $\mathrm{MgGa}(\mathrm{I})-0.06)$ observed in the IR spectra (Figure 3).

The zeta potential of the products is summarized in Table 1. The trend of the values correlated with the composition and the values are different from that of the commercial brucite, supporting the possible variation of layer charge density, which depends on the composition.

Table 1. Summary of the chemical composition, the estimated area per charge, the estimated layer charge density, and zeta potential of the products and the commercial brucite.

\begin{tabular}{|c|c|c|c|c|c|c|}
\hline Sample & $\begin{array}{c}\mathrm{X} \\
\text { (starting solution) }\end{array}$ & $\begin{array}{c}\mathrm{X} \\
\text { (products) }\end{array}$ & $\mathrm{Ga} / \mathrm{I}$ (products) & $\begin{array}{l}\text { Estimated Area per } \\
\text { Charge }\left(\mathrm{nm}^{2} /(+)\right)^{1}\end{array}$ & $\begin{array}{c}\text { Estimated Layer Charge } \\
\text { Density }\left((+) / \mathrm{nm}^{2}\right)^{2}\end{array}$ & $\begin{array}{l}\zeta \text {-Potential } \\
\quad(\mathrm{mV})\end{array}$ \\
\hline $\operatorname{MgGa}(\mathrm{I})-0.24$ & 0.25 & 0.24 & 2.0 & 0.35 & 2.86 & 38.71 \\
\hline $\operatorname{MgGa}(\mathrm{I})-0.18$ & 0.20 & 0.18 & 2.1 & 0.47 & 2.13 & NA. ${ }^{3}$ \\
\hline MgGa(I)-0.11 & 0.13 & 0.11 & 2.4 & 0.76 & 1.31 & 34.47 \\
\hline MgGa(I)-0.10 & 0.10 & 0.10 & 2.7 & 0.93 & 1.07 & NA. ${ }^{3}$ \\
\hline $\operatorname{MgGa}(\mathrm{I})-0.08$ & 0.09 & 0.08 & 2.9 & 1.07 & 0.93 & $\mathrm{NA}^{3}$ \\
\hline MgGa(I)-0.06 & 0.08 & 0.06 & 3.4 & 1.31 & 0.76 & 30.81 \\
\hline $\mathrm{Mg}(\mathrm{OH})_{2}$ & - & - & - & - & - & 16.94 \\
\hline
\end{tabular}

${ }^{1}$ Estimated area contains one positive charge $=\mathrm{a}^{2} \sin 60^{\circ} / \mathrm{x}$ [35]. ${ }^{2}$ Layer charge density $=1 /\left(\right.$ estimated area per charge). ${ }^{3}$ NA. $=$ not analyzed.

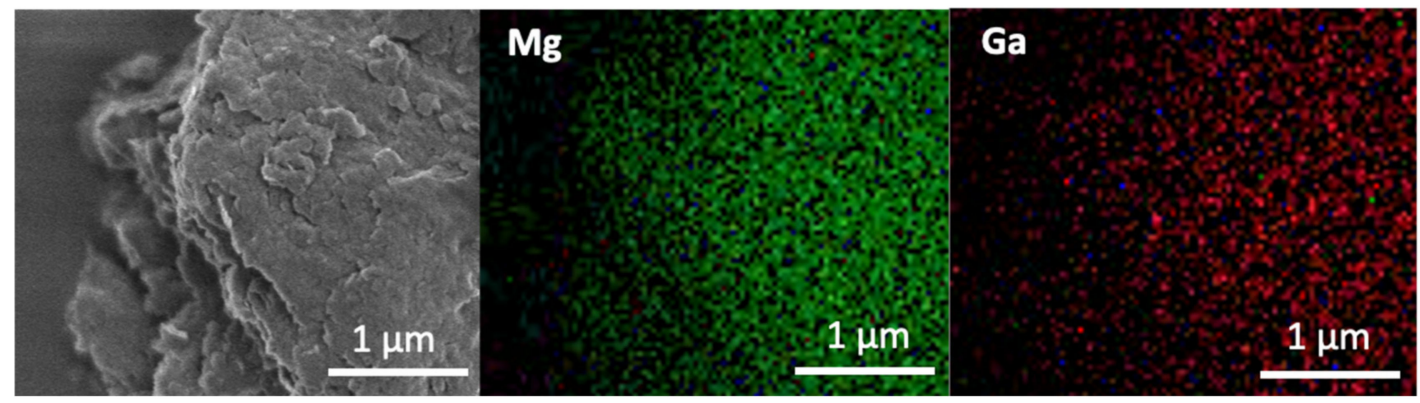

Figure 4. SEM image and elemental mapping of MgGa(I)-0.06. The element was presented by $\mathrm{Mg}$ (green) and Ga (red).

The area per charge (and the layer charge density) of $\mathrm{MgGa}(\mathrm{I})-0.24, \mathrm{MgGa}(\mathrm{I})-0.11$ and $\mathrm{MgGa}(\mathrm{I})-0.06$ were estimated from the $\mathrm{x}$ value and the lattice parameter $a$ of the products as summarized in Table 1. Due to the lower layer charge density, $\mathrm{MgGa}(\mathrm{I})-0.06$ was expected to be dispersed in water better if compared with $\mathrm{MgGa}(\mathrm{I})-0.24$. In order to accelerate the dispersion, the samples were freeze dried to obtain LDH particles with less aggregation for stable dispersion. The samples dried by heating and by freeze drying showed a difference in the particle aggregation, while the freeze-dried sample had a lower degree of aggregation. The difference derived from the drying method was seen by the SEM images of MgGa(I)0.06 and $\mathrm{MgGa}(\mathrm{I})-0.06 \_\mathrm{F}$ (Figure 5A,B). This difference is reflected to the apparent density as shown by the photograph of the samples in the capillary tube (Figure 5C), where $10 \mathrm{mg}$ of MgGa(I)-0.06_F had larger volume in the capillary than MgGa(I)-0.06 (corresponding to lower bulk density). Note that all samples exhibited platy particles in their SEM images to support the successful formation of LDHs. 


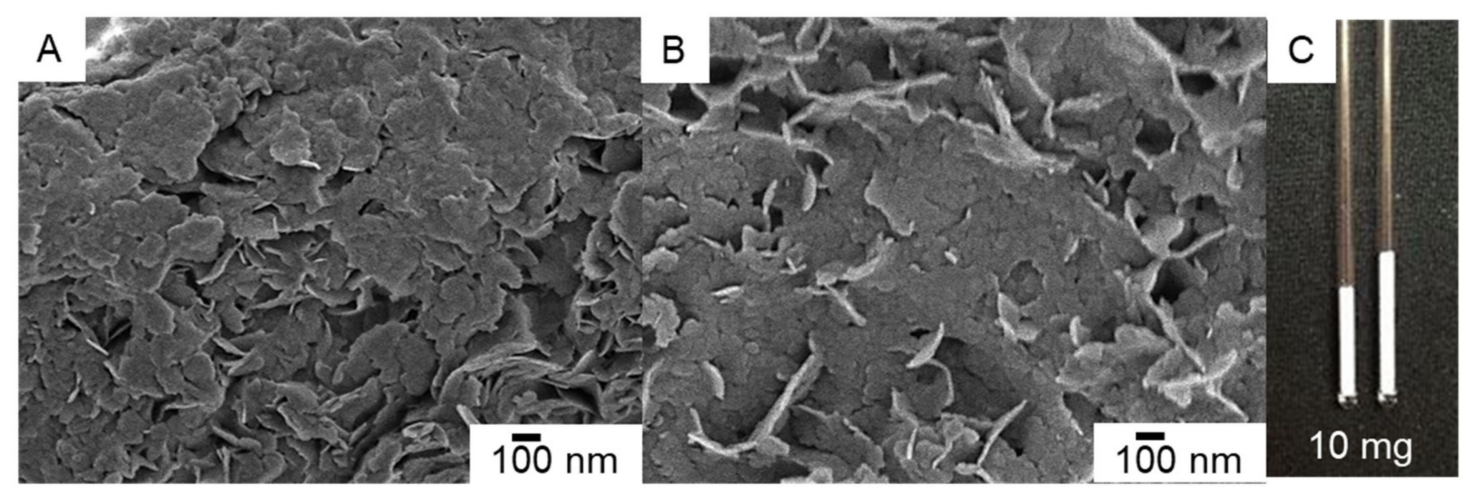

Figure 5. SEM images of MgGa(I)-0.06 (A) and MgGa(I)-0.06_F (B). (C) Photograph of the products in a capillary tube to show the difference in the density, $10 \mathrm{mg}$ of sample in the capillary without compressing; $\mathrm{MgGa}(\mathrm{I})-0.06$ (left) and MgGa(I)-0.06_F (right).

The XRD patterns of the freeze-dried samples (MgGa(I)-x_F, $x=0.24$ and 0.06) are shown in Figure 6 together with the corresponding samples dried by heating $(\mathrm{MgGa}(\mathrm{I})-\mathrm{x}$, $x=0.24$ and 0.06 ). For the products with $x$ of 0.24 , the (003) and (006) reflections with the $\mathrm{d}$ values of 0.82 and $0.41 \mathrm{~nm}$ were observed in both MgGa(I)-0.24 and MgGa(I)-0.24_F (Figure 6a,b), suggesting the regular stacking of iodide intercalation in the interlayer of the MgGa-LDH. On the contrary, for the products with x of 0.06, the XRD pattern of MgGa(I)-0.06 (Figure 6c) showed the characteristic reflections of interstratified structure with the basal spacings of 0.82 and $0.45 \mathrm{~nm}$ as schematically shown in Figure 2 . The (003) reflection was not seen for $\mathrm{MgGa}(\mathrm{I})-0.06$ F (Figure 6d), suggesting an irregular layer stacking. This difference between $\mathrm{MgGa}(\mathrm{I})-0.24 \_\mathrm{F}$ (regular stacking) and MgGa(I)-0.06_F (irregular stacking) was thought to be caused by the difference in the swelling due to the difference in the layer charge density, which is expected to correspond to the $x$ value.

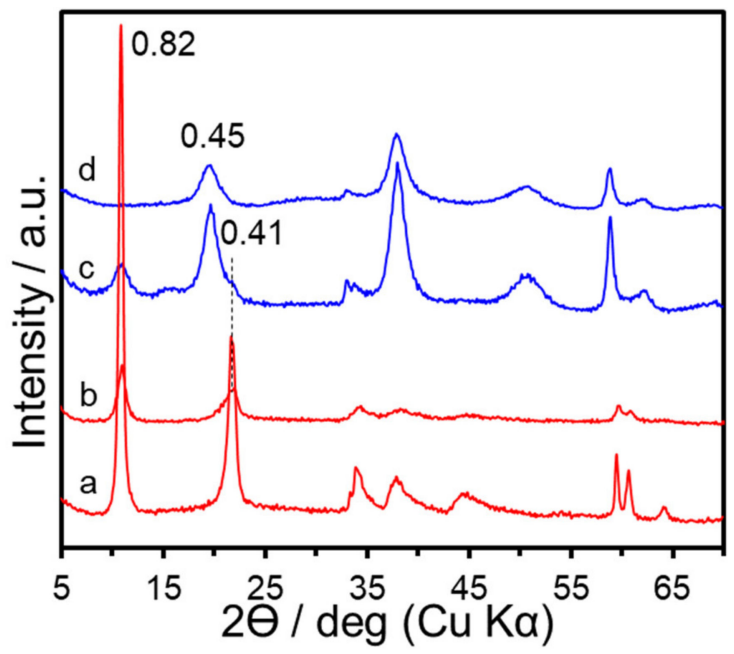

Figure 6. XRD patterns of MgGa(I)-0.24 (a), MgGa(I)-0.24_F (b), MgGa(I)-0.06 (c), and MgGa(I)$0.06 \_F(d)$.

The carbonate forms of LDH were prepared by the ion exchange with sodium carbonate. The ion exchange of the interlayer anion of LDHs results in the change in the interlayer spacing. To induce the ion exchange, the electrostatic interactions between LDH layer and exchanging anions should be larger than that between $\mathrm{LDH}$ layer and original anions $[12,36]$. The XRD patterns and IR spectra of $\mathrm{MgGa}\left(\mathrm{CO}_{3}\right)-0.24 \_\mathrm{F}$ and $\mathrm{MgGa}\left(\mathrm{CO}_{3}\right)-$ 0.06_F are shown in Figure 7A,B. $\mathrm{MgGa}\left(\mathrm{CO}_{3}\right)-0.24 \_\mathrm{F}$ showed the basal spacing of $0.78 \mathrm{~nm}$, which is consistent with the basal spacing of $\mathrm{MgGa}-\mathrm{LDH}$ containing carbonate anion as 
the interlayer anion [11], indicating the successful ion exchange of iodide and nitrate anions with carbonate. The results are in agreement with the reported sequence of the ion exchange of MgAl-LDH as the order of iodide < nitrate < carbonate [28]. The basal spacing of $\mathrm{MgGa}\left(\mathrm{CO}_{3}\right)-0.24 \_\mathrm{F}(0.78 \mathrm{~nm})$ was smaller than $\mathrm{MgGa}(\mathrm{I})-0.24 \_\mathrm{F}(0.82 \mathrm{~nm})$, which is related to the size of anions as $\mathrm{CO}_{3}{ }^{2-}=0.38 \mathrm{~nm}$ and $\mathrm{I}^{-}=0.42 \mathrm{~nm}$ [37-39]. For MgGa(CO3)-0.06_F, the (003) reflection was not observed in the XRD pattern as shown in Figure 7A, suggesting the irregular layer stacking. It was thought that the $\mathrm{MgGa}\left(\mathrm{CO}_{3}\right)-0.06 \_F$ swollen to some extent during the anion exchange thanks to the lower layer charge density, resulting in the irregular stacking by applying freeze drying. The anion exchange was indicated by the IR spectrum (Figure 7B), where the absorption due to the $\mathrm{C}-\mathrm{O}$ stretching vibration of carbonate anion in the interlayer was seen at $1376 \mathrm{~cm}^{-1}$. The layered structure was maintained after the ion exchange of the iodide with carbonate. This suggested that the collapsing of the layered structure in the previous studies [32,33] occurred during the formation (precipitation) of LDH and once layered structure formed, the structure was relatively stable to accommodate different anions by the ion exchange.
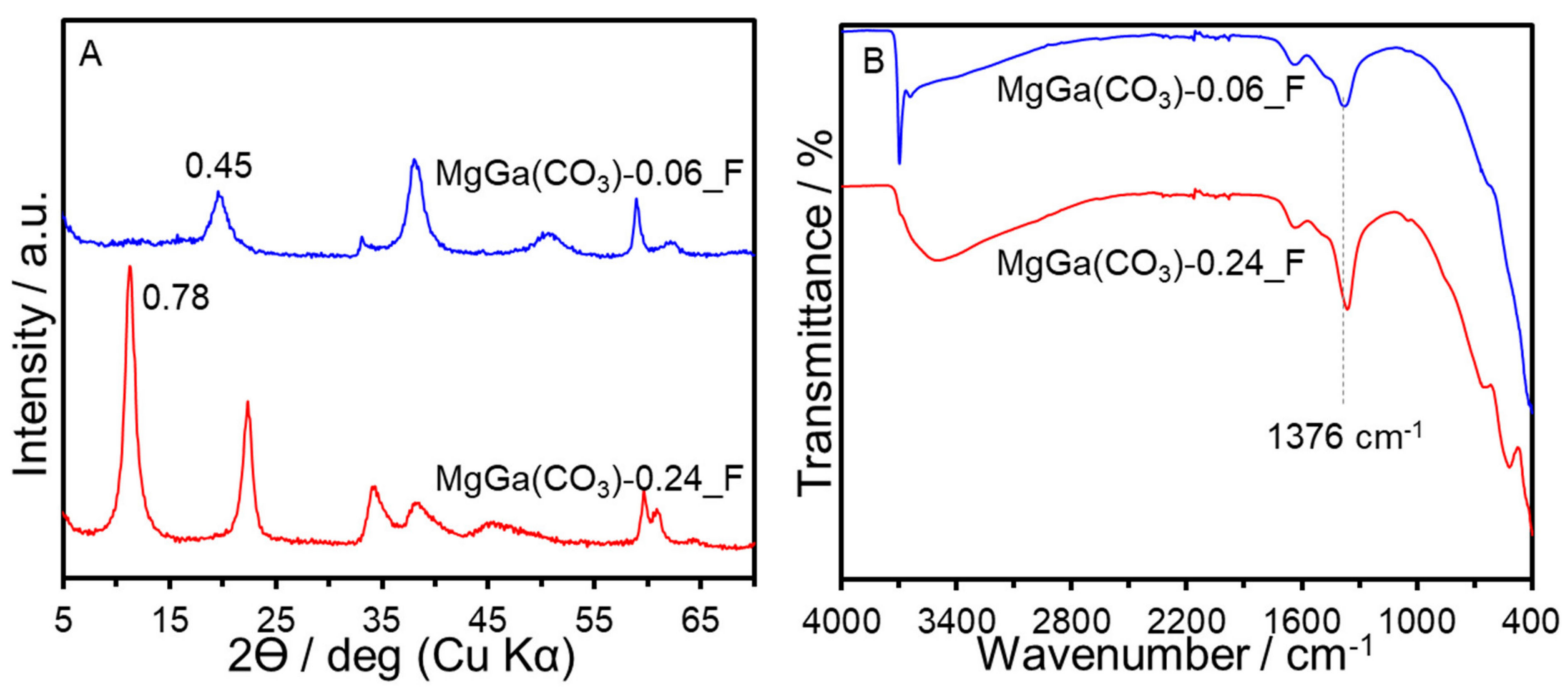

Figure 7. (A) XRD patterns and (B) IR spectra of $\mathrm{MgGa}\left(\mathrm{CO}_{3}\right)-0.24 \_\mathrm{F}$ and $\mathrm{MgGa}\left(\mathrm{CO}_{3}\right)-0.06 \_\mathrm{F}$.

Reconstruction of $\mathrm{MgGa}\left(\mathrm{CO}_{3}\right)-0.24 \_\mathrm{F}$ and $\mathrm{MgGa}\left(\mathrm{CO}_{3}\right)-0.06 \_\mathrm{F}$ were examined by the calcination at $500{ }^{\circ} \mathrm{C}$ and subsequent reaction with the aqueous solution of sodium dodecyl sulfate (SDS). The calcination of $\mathrm{MgGa}\left(\mathrm{CO}_{3}\right)-\mathrm{x} \_\mathrm{F}(\mathrm{x}=0.24$ and 0.06$)$ at $500{ }^{\circ} \mathrm{C}$ caused the dehydration, decarbonation, and dehydroxylation to give mixed metal oxides, which is known to form LDH structure by up-taking the anion from aqueous solution [16]. The transformation to the oxide by the calcination was confirmed by XRD patterns (Figure $8 \mathrm{~A}(\mathrm{~b}), \mathrm{B}(\mathrm{b})$ ), where diffraction peaks at $2 \theta$ of 36,42 , and $62^{\circ}$ (corresponding to the characteristic reflections of periclase (MgO) phase (JCPDS No. 04-0829)) were observed. The oxide reconstructed to the original LDH structures after the reaction with SDS as shown by the XRD patterns (Figure 8A(c),B(c)). The XRD pattern of MgGa(DS)-0.24_F exhibited the basal spacing of $2.8 \mathrm{~nm}$ (Figure $8 \mathrm{~A}$ (inset)), suggesting the incorporation of dodecyl sulfate (DS) anion in the interlayer space. If compared with the reported $\mathrm{MgAl}$ with $\mathrm{x}$ of 0.32 [40], the basal spacing of MgGa(DS)-0.24_F was smaller because of the difference in the layer charge density of the host. The layer charge density was reported to influence the orientation of DS in the interlayer space [41-43]. For MgGa(DS)-0.06_F, the (003) reflection was not seen in Figure 8B(c), suggesting the irregular stacking, which was thought to be caused by the swelling due to the lower layer charge density. The incorporation of DS anion in MgGa(DS)-0.06_F was confirmed by the absorption at 2922 and $2853 \mathrm{~cm}^{-1}$ due to $\mathrm{C}-\mathrm{H}$ stretching vibration and those at 1200 and $1058 \mathrm{~cm}^{-1}$ due to $\mathrm{S}=\mathrm{O}$ stretching vibration observed in the IR spectrum of MgGa(DS)-0.06_F (Figure 9). The IR results are consistent 
with those for the reported $\mathrm{MgAl} \mathrm{LDH}$ containing DS as the interlayer anion [44].
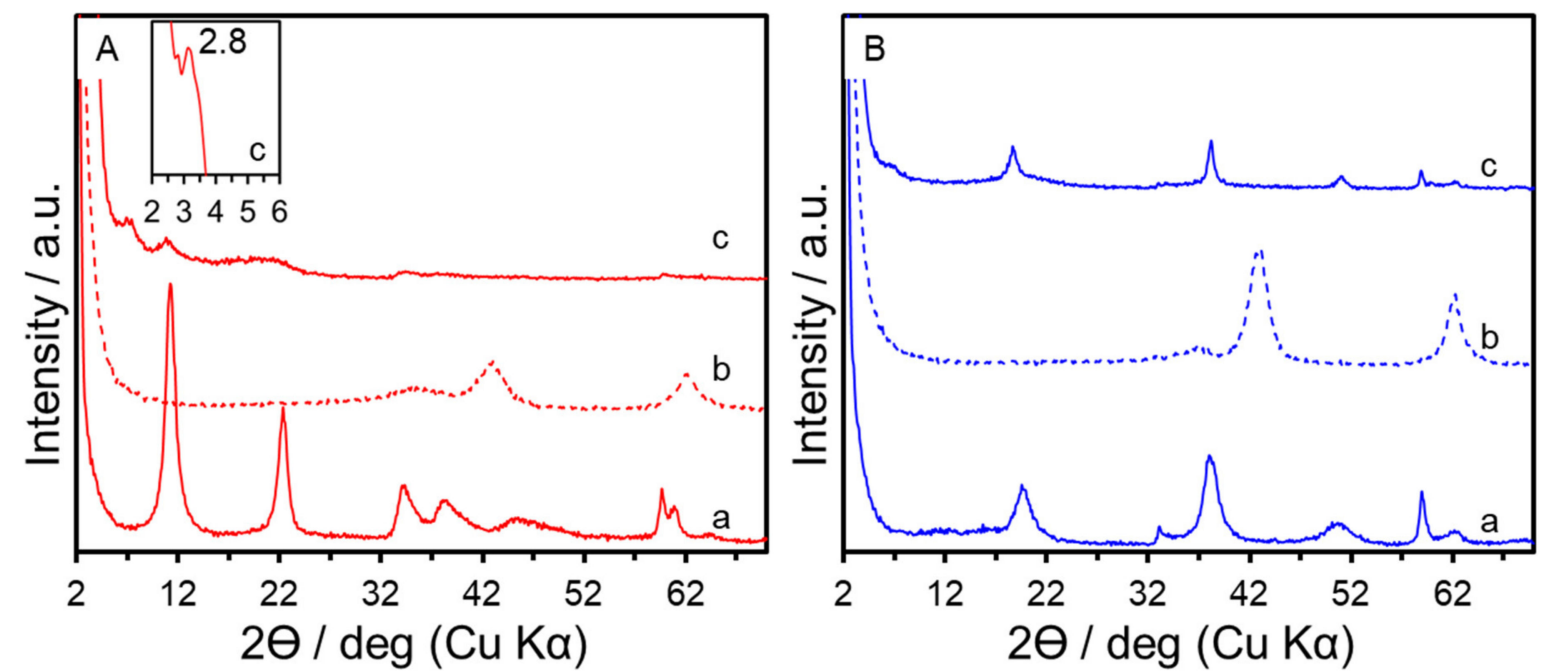

Figure 8. XRD patterns of $\mathrm{MgGa}\left(\mathrm{CO}_{3}\right)-\mathrm{x} \_\mathrm{F}(\mathrm{a})$, calcined $\mathrm{MgGa}\left(\mathrm{CO}_{3}\right)-\mathrm{x} \_\mathrm{F}(\mathrm{b})$, and $\mathrm{MgGa}(\mathrm{DS})-\mathrm{x} \_\mathrm{F}$ (c); $\mathrm{x}$ of 0.24 (A) and 0.06 (B). Inset: the (003) reflection of $\mathrm{MgGa}(\mathrm{DS})-0.24 \_\mathrm{F}$ at $2 \theta$ of $3^{\circ}$.

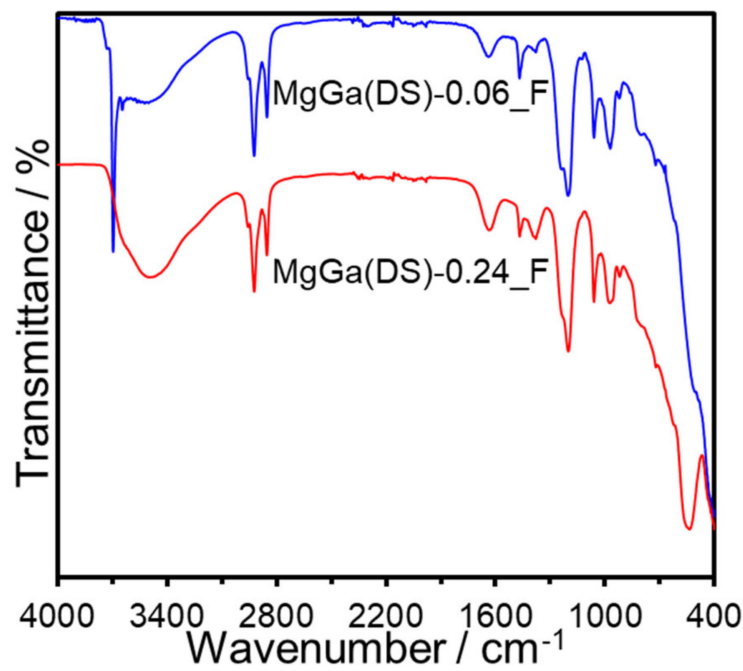

Figure 9. IR spectra of MgGa(DS)-0.24_F and MgGa(DS)-0.06_F.

The effect of $x$ value on the dispersion was examined using $\mathrm{MgGa}\left(\mathrm{CO}_{3}\right)-\mathrm{x} \_\mathrm{F}(\mathrm{x}=0.24$ and 0.06 ) to be dispersed in water. Figure $10 \mathrm{~A}, \mathrm{~B}$ shows the photograph of the dispersion before and after the storage for $6 \mathrm{~h}$ without agitation. $\mathrm{MgGa}\left(\mathrm{CO}_{3}\right)-0.24 \_\mathrm{F}$ sedimented while $\mathrm{MgGa}\left(\mathrm{CO}_{3}\right)-0.06 \_\mathrm{F}$ was dispersed. The dispersion of $\mathrm{MgGa}(\mathrm{DS})-\mathrm{x} \_\mathrm{F}(\mathrm{x}=0.24$ and 0.06 ) in hexanol was also examined and the appearance of the dispersion are shown in Figure 10C,D. MgGa(DS)-0.06_F was dispersed in hexanol, while MgGa(DS)-0.24_F sedimented. Since particles sizes were not different significantly for the samples, the difference in the dispersion behavior was thought to be a result of the difference in the layer charge density. 


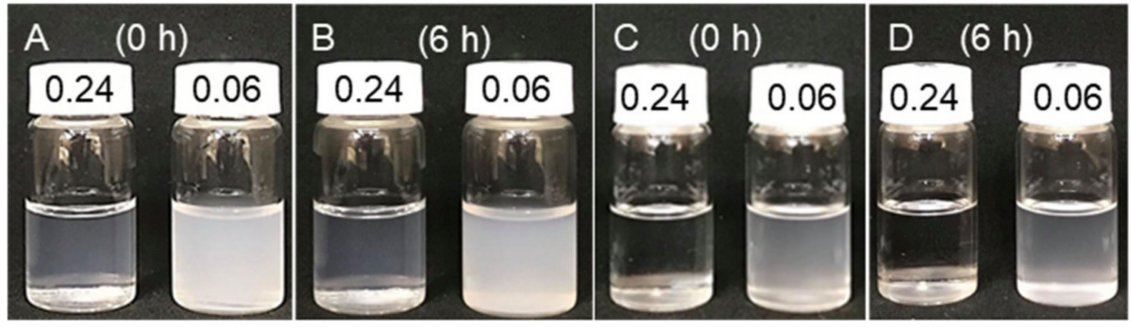

Figure 10. Photographs of dispersion of $\mathrm{MgGa}\left(\mathrm{CO}_{3}\right)-\mathrm{x} \_\mathrm{F}$ in water $(\mathbf{A}, \mathbf{B})$ and $\mathrm{MgGa}(\mathrm{DS})-\mathrm{x} \_\mathrm{F}$ in hexanol $(\mathbf{C}, \mathbf{D})$ before and after the storage for $6 \mathrm{~h}$.

\section{Conclusions}

$\mathrm{MgGa}-\mathrm{LDHs}$ with varied $\mathrm{x}$ of $0.06-0.24$ were prepared by coprecipitation using iodide as interlayer anion. The linear correlation between lattice parameter $a$ and the $\mathrm{x}$ values as well as the uniform distribution of $\mathrm{Mg}$ and Ga through the particles supported the successful substitution of $\mathrm{Mg}$ in the brucite-like sheet with Ga at x of 0.06-0.24. Interstratification was suggested for the sample with smaller $x$ values, while those with larger values of $0.18<x<0.24$ showed regular stacking of LDH layers with intercalated anion in c-axis. The zeta potential supported the possible variation of layer charge density due to the difference in the $x$ values. Once layered structures of the $\mathrm{MgGa}-\mathrm{LDH}$ with varied $\mathrm{x}$ formed, the $\mathrm{MgGa}-\mathrm{LDHs}$ with $\mathrm{x}$ of 0.06 and 0.24 were exchanged with carbonate by ion exchange and reconstructed with dodecyl sulfate after calcination, which were confirmed by the change in the basal spacing and the existence of stretching vibrations of the anions in the interlayer space. For the effect of $x$ value on the dispersion, the carbonate type $\mathrm{MgGa}-\mathrm{LDH}$ with $\mathrm{x}$ of 0.06 was dispersed in water and the MgGa-LDH with $\mathrm{x}$ of 0.06 containing dodecyl sulfate was dispersed in hexanol better than those of MgGa-LDHs with $x$ of 0.24 , suggesting possible effects of the layer charge density on the dispersion.

Author Contributions: Conceptualization, R.W. and M.O.; writing-original draft preparation, R.W., S.I. and M.O.; writing—review and editing, R.W., S.I. and M.O.; supervision, M.O. All authors have read and agreed to the published version of the manuscript.

Funding: This work was supported by the Research Chair Grant 2017 (grant number FDA-CO2560-5655) from the National Science and Technology Development Agency (NSTDA), Thailand and the Research Chair Grant 2020 (grant number B05F630117) from Program Management Unit (PMU) and Office of National Higher Education Science Research and Innovation Policy Council (NXPO), Thailand.

Data Availability Statement: The data presented in this study are available on request from the corresponding author.

Acknowledgments: R.W. and S.I. acknowledge Vidyasirimedhi Institute of Science and Technology for the scholarship to their Ph.D. study.

Conflicts of Interest: The authors declare no conflict of interest.

\section{References}

1. Liu, Y.; Gao, Y.; Wang, Q.; Lin, W. The synergistic effect of layered double hydroxides with other flame retardant additives for polymer nanocomposites: A critical review. Dalton Trans. 2018, 47, 14827-14840. [CrossRef]

2. Mishra, G.; Dash, B.; Pandey, S. Layered double hydroxides: A brief review from fundamentals to application as evolving biomaterials. Appl. Clay Sci. 2018, 153, 172-186. [CrossRef]

3. Choy, J.H.; Choi, S.J.; Oh, J.M.; Park, T. Clay minerals and layered double hydroxides for novel biological applications. Appl. Clay Sci. 2007, 36, 122-132. [CrossRef]

4. Fan, G.; Li, F.; Evans, D.G.; Duan, X. Catalytic applications of layered double hydroxides: Recent advances and perspectives. Chem. Soc. Rev. 2014, 43, 7040-7066. [CrossRef]

5. Yang, Z.; Wang, F.; Zhang, C.; Zeng, G.; Tan, X.; Yu, Z.; Zhong, Y.; Wang, H.; Cui, F. Utilization of LDH-based materials as potential adsorbents and photocatalysts for the decontamination of dyes wastewater: A review. RSC Adv. 2016, 6, 79415-79436. [CrossRef] 
6. Claverie, M.; Garcia, J.; Prevost, T.; Brendlé, J.; Limousy, L. Inorganic and hybrid (organic-inorganic) lamellar materials for heavy metals and radionuclides capture in energy wastes management-A review. Materials 2019, 12, 1399. [CrossRef] [PubMed]

7. Inomata, K.; Ogawa, M. Preparation and properties of Mg/Al layered double hydroxide-oleate and-stearate intercalation compounds. Bull. Chem. Soc. Jpn. 2006, 79, 336-342. [CrossRef]

8. Taviot-Guého, C.; Prévot, V.; Forano, C.; Renaudin, G.; Mousty, C.; Leroux, F. Tailoring hybrid layered double hydroxides for the development of innovative applications. Adv. Funct. Mater. 2018, 28, 1703868. [CrossRef]

9. Wijitwongwan, R.P.; Intasa-ard, S.G.; Ogawa, M. Preparation of layered double hydroxides toward precisely designed hierarchical organization. Chem. Eng. 2019, 3, 68. [CrossRef]

10. Intasa-Ard, G.S.; Imwiset, J.K.; Bureekaew, S.; Ogawa, M. Mechanochemical methods for the preparation of intercalation compounds, from intercalation to the formation of layered double hydroxides. Dalton Trans. 2018, 47, 2896-2916. [CrossRef]

11. Rives, V. Layered Double Hydroxides: Present and Future; Nova Science Publishers Inc.: New York, NY, USA, 2001.

12. Evans, D.G.; Slade, R.C.T. Structural aspects of layered double hydroxides. Struct. Bond. 2006, 119, 1-87.

13. Mascolo, G.; Marino, O. A new synthesis and characterization of magnesium-aluminium hydroxides. Miner. Mag. 1980, 43, 619-621. [CrossRef]

14. Lee, J.Y.; Gwak, G.H.; Kim, H.M.; Kim, T.I.; Lee, G.J.; Oh, J.M. Synthesis of hydrotalcite type layered double hydroxide with various $\mathrm{Mg} / \mathrm{Al}$ ratio and surface charge under controlled reaction condition. Appl. Clay Sci. 2016, 134, 44-49. [CrossRef]

15. Bellotto, M.; Rebours, B.; Clause, O.; Lynch, J.; Bazin, D.; Elkaïm, E. A reexamination of hydrotalcite crystal chemistry. J. Phys. Chem. 1996, 100, 8527-8534. [CrossRef]

16. Miyata, S. Physico-chemical properties of synthetic hydrotalcites in relation to composition. Clays Clay Miner. 1980, $28,50-56$. [CrossRef]

17. Brindley, G.W.; Kikkawa, S. A crystal-chemical study of $\mathrm{Mg}, \mathrm{Al}$ and Ni, N hydroxy-perchlorates and hydroxycarbonates. Am. Mineral. 1979, 64, 836-843.

18. Kooli, F.; Chisem, I.C.; Vucelic, M.; Jones, W. Synthesis and properties of terephthalate and benzoate intercalates of mg- Al layered double hydroxides possessing varying layer charge. Chem. Mater. 1996, 8, 1969-1977. [CrossRef]

19. Ogawa, M.; Asai, S. Hydrothermal synthesis of layered double hydroxide- deoxycholate intercalation compounds. Chem. Mater. 2000, 12, 3253-3255. [CrossRef]

20. Milagres, J.L.; Bellato, C.R.; Vieira, R.S.; Ferreira, S.O.; Reis, C. Preparation and evaluation of the Ca-Al layered double hydroxide for removal of copper (II), nickel (II), zinc (II), chromium (VI) and phosphate from aqueous solutions. J. Environ. Chem. Eng. 2017, 5, 5469-5480. [CrossRef]

21. Sipiczki, M.; Kuzmann, E.; Homonnay, Z.; Megyeri, J.; Pálinkó, I.; Sipos, P. The structure and stability of CaFe layered double hydroxides with various Ca:Fe ratios studied by Mössbauer spectroscopy, X-ray diffractometry and microscopic analysis. J. Mol. Struct. 2013, 1044, 116-120. [CrossRef]

22. Ma, R.; Liang, J.; Takada, K.; Sasaki, T. Topochemical synthesis of Co-Fe layered double hydroxides at varied Fe/Co ratios: Unique intercalation of triiodide and its profound effect. J. Am. Chem. Soc. 2011, 133, 613-620. [CrossRef]

23. Ma, R.; Liang, J.; Liu, X.; Sasaki, T. General insights into structural evolution of layered double hydroxide: Underlying aspects in topochemical transformation from brucite to layered double hydroxide. J. Am. Chem. Soc. 2012, 134, 19915-19921. [CrossRef] [PubMed]

24. Caravaggio, G.A.; Detellier, C.; Wronski, Z. Synthesis, stability and electrochemical properties of NiAl and NiV layered double hydroxides. J. Mater. Chem. 2001, 11, 912-921. [CrossRef]

25. Shannon, R.D. Revised effective ionic radii and systematic studies of interatomic distances in halides and chalcogenides. Acta Cryst. 1976, 32, 751-767. [CrossRef]

26. Stepanova, L.N.; Belskaya, O.B.; Salanov, A.N.; Serkova, A.N.; Likholobov, V.A. SEM study of the surface morphology and chemical composition of the $\mathrm{MgAl}$-and $\mathrm{MgGa}$-layered hydroxides in different steps of platinum catalysts $\mathrm{Pt} / \mathrm{Mg}(\mathrm{Al}, \mathrm{Ga}) \mathrm{Ox}$ synthesis. Appl. Clay Sci. 2018, 157, 267-273. [CrossRef]

27. Johnsen, R.E.; Wu, Q.; Sjåstad, A.O.; Vistad, Ø.B.; Krumeich, F.; Norby, P. Nanostructured materials produced by mixing and restacking of delaminated layered double hydroxides. J. Phys. Chem. 2008, 112, 16733-16739. [CrossRef]

28. Petersen, L.B.; Lipton, A.S.; Zorin, V.; Nielsen, U.G. Local environment and composition of magnesium gallium layered double hydroxides determined from solid-state $1 \mathrm{H}$ and 71Ga NMR spectroscopy. J. Solid State Chem. 2014, 219, 242-246. [CrossRef]

29. Sasaki, T.; Kooli, F.; Iida, M.; Michiue, Y.; Takenouchi, S.; Yajima, Y.; Izumi, F.; Chakoumakos, B.C.; Watanabe, M. A mixed alkali metal titanate with the lepidocrocite-like layered structure. Preparation, crystal structure, protonic form, and acid- base intercalation properties. Chem. Mater. 1998, 10, 4123-4128. [CrossRef]

30. Miyata, S. Anion-exchange properties of hydrotalcite-like compounds. Clay Clay Miner. 1983, 31, 305-311. [CrossRef]

31. Carteret, C.; Grégoire, B.; Ruby, C. Tunable composition of NiII-AlIII and NiII-FeIII layered hydroxides within a wide range of layer charge. Solid State Sci. 2011, 13, 146-150. [CrossRef]

32. López-Salinas, E.; García-Sánchez, M.; Ramon-Garcia, M.L.; Schifter, I. New Gallium-substituted hydrotalcites: [Mg1-xGax (OH)2](CO3)x/2· mH2O. J. Porous Mater. 1996, 3, 169-174. [CrossRef]

33. López-Salinas, E.; Garcia-Sanchez, M.; Montoya, J.A.; Acosta, D.R.; Abasolo, J.A.; Schifter, I. Structural characterization of synthetic hydrotalcite-like [Mg1-x $\operatorname{Gax}(\mathrm{OH}) 2](\mathrm{CO}) \mathrm{x} / 2 \cdot \mathrm{mH} 2 \mathrm{O}$. Langmuir 1997, 13, 4748-4753. [CrossRef] 
34. Miyata, S. The syntheses of hydrotalcite-like compounds and their structures and physico-chemical properties- $\mathrm{I}$ : The systems Mg2+-Al3+-NO3-, Mg2+-Al3+-Cl-, Mg2+-Al3+-ClO4-, Ni2+-Al3+-Cl- and Zn2+-Al3+-Cl-. Clay Clay Miner. 1975, 23, 369-375. [CrossRef]

35. Xu, Z.P.; Zeng, H.C. Abrupt structural transformation in hydrotalcite-like compounds $\mathrm{Mg} 1-\mathrm{xAlx}(\mathrm{OH}) 2(\mathrm{NO} 3) \mathrm{x} \cdot \mathrm{nH} 2 \mathrm{O}$ as a continuous function of nitrate anions. J. Phys. Chem. B 2001, 105, 1743-1749. [CrossRef]

36. Palin, L.; Milanesio, M.; Van Beek, W.; Conterosito, E. Understanding the ion exchange process in LDH nanomaterials by fast in situ XRPD and PCA-assisted kinetic analysis. J. Nanomater. 2019, 2019. [CrossRef]

37. Iyi, N.; Fujii, K.; Okamoto, K.; Sasaki, T. Factors influencing the hydration of layered double hydroxides (LDHs) and the appearance of an intermediate second staging phase. Appl. Clay Sci. 2007, 35, 218-227. [CrossRef]

38. Zhao, X.J.; Zhu, Y.Q.; Xu, S.M.; Liu, H.M.; Yin, P.; Feng, Y.L.; Yan, H. Anion exchange behavior of MIIAl layered double hydroxides: A molecular dynamics and DFT study. Phys. Chem. Chem. Phys. 2020, 22, 19758-19768. [CrossRef]

39. Roobottom, H.K.; Jenkins, H.D.B.; Passmore, J.; Glasser, L. Thermochemical radii of complex ions. J. Chem. Educ. 1999, 76, 1570. [CrossRef]

40. Toson, V.; Conterosito, E.; Palin, L.; Boccaleri, E.; Milanesio, M.; Gianotti, V. Facile intercalation of organic molecules into hydrotalcites by liquid-assisted grinding: Yield optimization by a chemometric approach. Crys. Growth Des. 2015, 15, 5368-5374. [CrossRef]

41. Meyn, M.; Beneke, K.; Lagaly, G. Anion-exchange reactions of layered double hydroxides. Inorg. Chem. 1990, $29,5201-5207$. [CrossRef]

42. Naik, V.V.; Vasudevan, S. Effect of alkyl chain arrangement on conformation and dynamics in a surfactant intercalated layered double hydroxide: Spectroscopic measurements and MD simulations. J. Phys. Chem. C 2011, 115, 8221-8232. [CrossRef]

43. Clearfield, A.; Kieke, M.; Kwan, J.; Colon, J.L.; Wang, R.C. Intercalation of dodecyl sulfate into layered double hydroxides. J. Incl. Phenom. Mol. Recognit. Chem. 1991, 11,361-378. [CrossRef]

44. Alansi, A.M.; Alkayali, W.Z.; Al-qunaibit, M.H.; Qahtan, T.F.; Saleh, T.A. Synthesis of exfoliated polystyrene/anionic clay MgAl-layered double hydroxide: Structural and thermal properties. RSC Adv. 2015, 5, 71441-71448. [CrossRef] 